\title{
Vitamin D Receptor Gene Polymorphism Fokl and 25-Hydroxy Vitamin D Levels among Indonesian Diabetic Foot Patients
}

\author{
Raflis Raflis ${ }^{1 *}$, Hendro Sudjono Yuwono ${ }^{2}$, Yanwirasti Yanwirasti ${ }^{3}$, Eva Decroli ${ }^{4}$ \\ ${ }^{1}$ Department of Surgery, Faculty of Medicine, Andalas University, Padang, West Sumatera, Indonesia; ${ }^{2}$ Department of Surgery, \\ Faculty of Medicine, University of Padjadjaran, Bandung, West Java, Indonesia; ${ }^{3}$ Department of Anatomy, Faculty of Medicine, \\ Andalas University, Padang, West Sumatera, Indonesia; ${ }^{4}$ Department of Internal Medicine, Faculty of Medicine, Andalas \\ University, Padang, West Sumatera, Indonesia
}

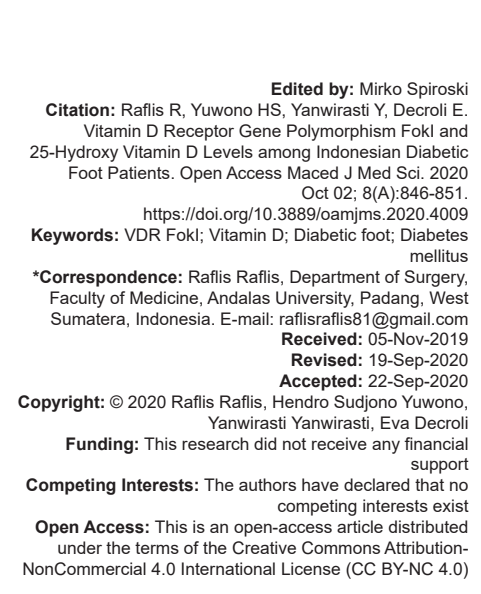

\section{Introduction}

The most common microvascular complication of type 2 diabetes mellitus (T2DM) is diabetic foot with the prevalence around 25\% [1], [2]. The process is initiated by chronic hyperglycemia, endothelial dysfunction, and cytokines secretion which result in chronic inflammation, decreasing nitric oxide (NO) production, and triggering atherosclerosis [2], [3], [4]. Clinically, skin lesions found in diabetic foot patients can develop into gangrene and chronic inflammation, with an increased risk of secondary infections, and a $2 \%$ chance of amputation [5]. Therefore, disruption of patient movement and reduction of individual activity lead to a disabling condition.

Vitamin D, known as the sunshine vitamin, has been understood as an important key for controlling inflammation of endothelial cells, through
Vitamin D receptors (VDRs). Hypo vitamin D and VDR polymorphisms are strongly associated with diabetes and cardiovascular diseases [6], [7], [8], [9]. The genetic role of Vitamin D in T2DM has been well-demonstrated, and different variants of VDR gene Fokl are associated with T2DM [10], [11], [12], [13]. The human VDR genes are located in chromosome 12q12-q14, and the Fokl polymorphism (ATG-ACG) are in the exon 2 of the gene, with a unique function to change the structure of the VDR protein and then produce two different protein variants. Fokl gene with $f$ allele ( $T$ amino acid) encodes 427 amino acid proteins while the $\mathrm{F}$ allele $(\mathrm{C}$ amino acid) encodes 424 amino acid proteins [11], [14]. It makes the shorter variant increases its binding capacity to 1, 25-dihydroxyvitamin D [15].

The higher level of Vitamin D might enhance pancreatic $\beta$-cell secretion function and improve insulin resistance [12]. However, the biological association between the absent of allele in Fokl polymorphisms and 
the susceptibility to T2DM cannot be clearly determined due the wide variety of study methods [16], [17]. This study aimed to determine the status of Vitamin $D$ and to detect the FokI VDR polymorphisms among diabetic foot patients in sunlight-rich areas.

\section{Materials and Methods}

\section{Research ethics}

Ethics clearance was approved by the Ethics Committee of Medical Faculty of Andalas University (No: 297/KEP/FK/ 2016). Written informed consent was obtained from all subjects before the start of the study, after they got information about the procedures.

\section{Patients}

This is part of the study on the effect of Vitamin D supplementation in diabetic foot patients. Diabetic foot outpatients treated at Ibnu Sina and Dr. Rasyidin General Hospital, aged 40-65 years, had $\mathrm{HbA} 1 \mathrm{c}$ level $>6.5 \%$ (normal <6.5), and ankle-brachial index $(A B I)$ between 0.4 and 1.2 (normal $0.9-1.3$ ) were included in this study. Diagnosis and clinical treatment of T2DM were performed by internists or endocrinologists. T2DM patients with arterial complications: Occlusion, bleeding, and with organ diseases that affected Vitamin D metabolism such as osteoporosis, hypoparathyroidism, the complication of diabetic or hypertension, ankle lesions or ulcers, infection, and sepsis were excluded from the study.

\section{Samples}

Sample collections began with initial selection through patients medical records. Subjects fulfilled the inclusion and exclusion criteria were selected consecutively. A questionnaire for symptom-based screening and $\mathrm{ABI}$ examination was performed by vascular surgeons. Demographic data on age, gender, body weight, and height were recorded. Fasting blood glucose, $\mathrm{HbA} 1 \mathrm{c}$, Vitamin D levels, and VDR Fokl genetic polymorphisms were examined. Vitamin $D$ serum levels were measured by electroimmunoassay (ECLIA) using a COBAS analyzer at Biomedical Laboratory of Medical Faculty of Andalas University and were classified as sufficiency $>30 \mathrm{ng} / \mathrm{mL}$ (75-80 nM), insufficiency 20-30 ng/mL (75-80 nM), and deficiency $<20 \mathrm{ng} / \mathrm{mL}(50 \mathrm{nM})$ [18].

\section{Polymerase chain reaction (PCR)}

DNA isolation, amplification, and restrictions were done to get the PCR results. The isolation process was carried out using the PureLink ${ }^{\mathrm{TM}}$ Genomic
DNA Mini Kit Invitrogen, through DNA incubation and homogenization at $55^{\circ} \mathrm{C}$, followed by centrifuge $1000 \mathrm{~g}$ for 10 min to binding, washing with $500 \mu$ l wash buffer 1 twice and then DNA eluting.

Furthermore, Fokl VDR gene amplification was carried out by PCR process using PCR solutions that consist of $12.5 \mu \mathrm{l}$ Go Tag Green Master Mix (Promega), $1 \mu \mathrm{l}$ Primer Forward VDR Fokl $(10 \mu \mathrm{M})$, $1 \mu \mathrm{l}$ Primer Reverse VDR Fokl $(10 \mu \mathrm{M}), 3 \mu \mathrm{I}$ DN, and $7.5 \mu \mathrm{l}$ Nuclease Free Water, for total volume $25 \mu \mathrm{l}$. The PCR cycle conditions were denaturation at $95^{\circ} \mathrm{C}$ for $3 \mathrm{~min}$, followed by 35 cycles initial denaturation at $95^{\circ} \mathrm{C}$ for $30 \mathrm{~s}$, annealing at $59^{\circ} \mathrm{C}$ for $30 \mathrm{~s}$, elongation at $72^{\circ} \mathrm{C}$ for $55 \mathrm{~s}$ and the last elongation at $72^{\circ} \mathrm{C}$ for $5 \mathrm{~min}$. Electrophoresis process was been done for $60 \mathrm{~min}$ on $1.5 \%$ agarose gel resulting PCR product with length 250 base pair (bp).

Restrictions process was done using Restriction Fragment Length Polymorphism-PCR methods with Fokl restriction enzyme, forward primer (5'-CACTGACTCTGGCTCTGACCGT-3'), and reverse primer (5'-AACACCTTGCTTCTTCTCCCTCC-3') [14]. The $3 \mu \mathrm{l}$ PCR amplicon with $1 \mu \mathrm{l}$ Fokl restriction enzyme, $2 \mu \mathrm{l}$ Buffer Green, and $24 \mu \mathrm{l}$ Nuclease Free Water for total restriction reaction volume of $30 \mu$ l were digested overnight at $37^{\circ} \mathrm{C}$. All digest products were analyzed by electrophoresis on a $1.5 \%$ agarose gel for $60 \mathrm{~min}$ at $120 \mathrm{~V}$, resulting PCR products with length 192 and $58 \mathrm{bp}$ for homozygous (TT) and 250, 192, and 58 bp for heterozygous samples (TC) and homozygous CC remained uncut. Some of the amplification results were sent for sequencing at Macrogen Laboratory, South Korea.

\section{Data analysis}

We analyzed data using SPSS Statistics version 22.0 (IBM, NY, USA). Descriptive statistics was used to describe the characteristics of the study population, including age, sex, disease duration, blood sugar levels, HbA1c, and Vitamin D levels. One-way ANOVA (for normally distributed variables) or Kruskal-Wallis (for non-parametric variables) tests were used to evaluate the difference between explanatory variables across different genotypes of VDR Fokl.

\section{Results}

\section{Characteristic of study subjects}

Characteristics of diabetic foot subjects are shown in Table 1. Of 36 subjects, $52.8 \%$ were female, $61.1 \%<50$ years, $63.9 \%$ had normal body mass index (BMI), and most of them with normal $A B I(86.1 \%)$. 
Table 1: Demographic characteristic in diabetic foot subjects

\begin{tabular}{ll}
\hline Variable & $\mathrm{n}(\%)$ \\
\hline Age & \\
$\geq 50$ years old & $14(38.9)$ \\
$<50$ years old & $22(61.1)$ \\
Gender & \\
$\quad$ Female & $19(52.8)$ \\
BMI & \\
$\quad$ Underweight & $2(5.6)$ \\
Normal & $23(63.9)$ \\
Overweight & $9(25.0)$ \\
Obese & $2(5.6)$ \\
ABI & \\
$0.4-0.9$ & $4(11.1)$ \\
$0.9-1.3$ & $31(86.1)$ \\
$>1.3$ & $1(2.8)$ \\
Vitamin D status & $7(19.4)$ \\
Deficiency & $12(33.3)$ \\
Insufficiency & $17(47.3)$ \\
Sufficiency & \\
VDR genotype & $5(13.9)$ \\
Wild type (ff) & $16(44.4)$ \\
Heterozygote mutant (Ff) & $15(41.7)$ \\
Homozygote mutant (FF) & \\
\hline ABI: Ankle brachial index, BMI: Body mass index &
\end{tabular}

ABI: Ankle brachial index, BMl: Body mass index.

Vitamin D deficiency, insufficiency, and sufficiency were observed in $19.4 \%, 33.3 \%$, and $47.2 \%$ of the study subjects, respectively. The majority of the subjects had Fokl VDR gene polymorphisms, that is, mutant heterozygous $\mathrm{Ff}(44.4 \%)$ and mutant homozygous $\mathrm{FF}$ $(41.7 \%)$.

Results from one-way ANOVA and KruskalWallis tests showed that there were no differences $(p>0.05$ ) of $\mathrm{BMI}, \mathrm{ABI}$, fasting blood glucose, Hb1AC level, and Vitamin $D$ levels across VDR Fokl genotypes (Table 2).

Table 2: Mean of variables based on VDR Fokl genotypes

\begin{tabular}{lllll}
\hline Variable (mean) & \multicolumn{3}{l}{ VDR Fokl genotypes } & p-value \\
\cline { 2 - 4 } & $\mathrm{ff}($ mean $\pm \mathrm{SD})$ & $\mathrm{Ff}($ mean $\pm \mathrm{SD})$ & $\mathrm{FF}($ mean $\pm \mathrm{SD})$ & \\
\hline $\mathrm{BMI}$ & $20.6 \pm 4.1$ & $23.9 \pm 4.4$ & $23.3 \pm 3.9$ & $0.335^{*}$ \\
$\mathrm{ABI}$ & $1.04 \pm 0.09$ & $1.06 \pm 0.17$ & $0.99 \pm 0.15$ & $0.604^{* *}$ \\
Fasting blood glucose & $202.8 \pm 65.7$ & $174.6 \pm 74.7$ & $154.3 \pm 75.2$ & $0.345^{* *}$ \\
$(\mathrm{mg} / \mathrm{dL})$ & & & & \\
Vitamin D $(\mathrm{ng} / \mathrm{mL})$ & $35.8 \pm 13.5$ & $28.9 \pm 9.4$ & $29.0 \pm 10.2$ & $0.399^{*}$ \\
HbA1c $(\%)$ & $11.2 \pm 2.4$ & $10.3 \pm 2.6$ & $9.9 \pm 2.0$ & $0.537^{*}$ \\
\hline${ }^{*}$ One-way ANOVA test, ${ }^{* *}$ Kruskal-Wallis test. ABl: Ankle brachial index, BMl: Body mass index.
\end{tabular}

After stratifying subjects based on VDR Fokl genotypes and Vitamin D levels, we found that most of the Vitamin D deficiency subjects had VDR Fokl heterozygous mutant $\mathrm{Ff}(31.2 \%)$ and none of them had homozygous wild type $\mathrm{ff}(0 \%)$ (Figure 1$)$, no statistical significant differences were observed $(p>0.05)$. When we classified as allele subgroups, all VDR Fokl gene with $\mathrm{F}$ allele mutant had more frequent Vitamin $\mathrm{D}$ deficiency status than $f$ allele $(54.8 \%$ vs. $40 \%)$, on the other hand in sub group VDR Fokl with $f$ allele wild type,

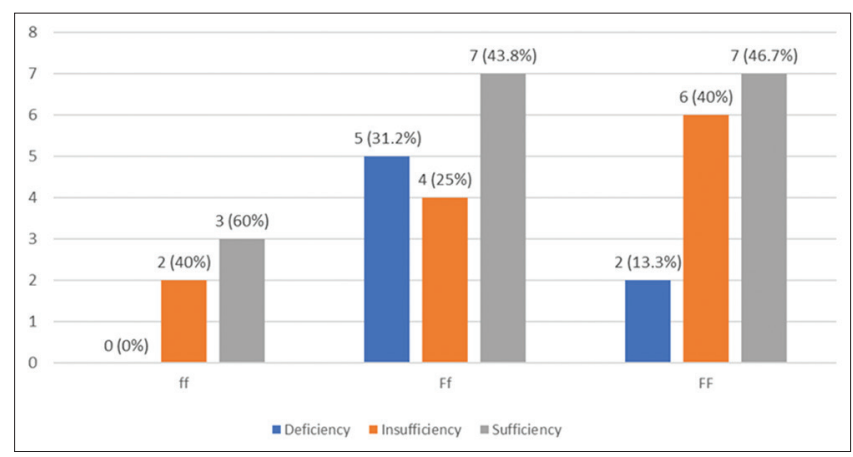

Figure 1: Diagram of Vitamin D status based on VDR Fokl genotype subgroups $(p>0.05)$
Vitamin $\mathrm{D}$ deficiency status is not frequent as compare to F allele ( $45.2 \%$ vs. $60 \%$ ).

\section{Discussion}

Diabetic foot is the most common micro vascular complications in T2DM. Factors associated with its development have not been fully understood, but many studies assume that it occurs secondary to micro angiopathy due to late diabetic complications. The involvement of Vitamin D and VDR Fokl gene polymorphisms has been suggested in the development of worsening inflammation in T2DM [12], [13].

In the present study, $61.1 \%$ of the diabetic foot patients were $<50$ years old. This is relatively different with results from other studies. Two studies of the Indonesian population in other regions such as Manado and Denpasar reported that the majority of diabetic patients were $\geq 50$ years $(76.3 \%)$ and $50-59$ years $(46.9 \%)$, respectively [19], [20]. Other reports from India and a meta-analysis also provide data that diabetic foot was predominantly shown in older patients (aged >50 years) [21], [22], [23], [24]. This difference might due to the high proportion of patients $(33.3 \%)$ in our study being diagnosed with T2DM when they were $<40$ years old. This condition might have resulted in an earlier worsening of vascular endothelium due to the long-term chronic hyperglycemia. Consistent with the other studies, a positive association was shown between foot ulcer and age [25], [26].

In our study, the proportion of females with diabetic foot was higher than males and females were more likely to develop T2DM at an earlier age than males. This is supported by another study in Lampung, Indonesia, showing that the prevalence of diabetic foot females was higher than males (65\% vs. $34.7 \%)$ [27]. This is possibly due to cultural reasons, given that most of the Indonesian women are housewife, getting married at an early age, and not frequently doing outdoor activities. In addition, most of the Indonesian women are Moslems wearing full-body garments. This lack of exposure to sunlight might prevent the synthesis of Vitamin D, causing Vitamin D deficiency and diabetes. This finding is similar to another study by Malik et al. in the Kashmir valley [28]. In contrast, a meta-analysis showed that males were relatively more frequent to develop T2DM than females (11.2 vs. $9.91 \%$ ) [29]. Another study also reported that males had 2.2 times higher incidence and prevalence of diabetic foot compared to females, caused by higher physical activity that contributes to diabetic ulcers [30].

In general, diabetic foot patients in our study had normal BMI. Among individuals who had VDR Fokl with $F$ allele, BMI values were higher than those with $f$ allele, but no statistical difference was observed. Some studies provide evidence that body size (reflected by BMI) has 
relationships with either Vitamin D levels or VDR [31], [32]. VDR is present in adipocytes and plays a role in modulating this active metabolic tissue in obese individuals [33]. Caron et al. reported that Vitamin D was negatively associated with adipocyte size, but this association was only shown in women [34]. This might explain our insignificant difference of BMI between these two VDR Fokl alleles, as our study population was dominated by females. However, the relationship between VDR Fokl polymorphisms and BMI is not consistent; some studies reported no significant association [31], [32], whereas other studies found an association between both of them [35].

Low Vitamin D levels have been associated with an increase in cytokine concentrations in diabetic foot subjects causing delayed wound healing [36]. In this study, $52.7 \%$ of diabetic foot subjects had Vitamin D levels $<20 \mathrm{ng} / \mathrm{mL}(33.3 \%$ insufficiency and $19.4 \%$ deficiency). A study in multi-ethnic subjects at risk for T2DM also reported similar conditions where Vitamin D levels were significantly associated to insulin resistance and beta-cell dysfunction [37]. These findings highlight the importance of Vitamin $D$ to the development of inflammation in T2DM patients [36], [38].

Our results revealed that the frequencies of both mutant VDR Fokl Ff (44.4\%) and FF (13.9\%) genotypes were higher and tended to have lower Vitamin $\mathrm{D}$ levels compared to wild type alleles (ff) among diabetic foot subjects. Several reports on the effect of VDR polymorphisms to basal serum Vitamin D levels due to insulin secretion and necessary to maintain glucose tolerance [39], [40]. There has been known that the Fokl single-nucleotide polymorphism is capable of changing the protein structure and produces two different protein variants with different activities [10], [11]. The T allele changing into the $C$ allele is suspected to affect insulin sensitivity [11], [14]. It is possible that genetic variants of the VDR gene may contribute to the development of diabetes [40]. However, it remains inconsistent, since a meta-analysis showed no significant relationship between VDR polymorphisms and risk of T2DM among Asian population [13].

Our study has some limitation that should be acknowledged. As this study only aimed to evaluate the association of Vitamin D levels with VDR Fokl polymorphisms, the cause of Vitamin $D$ deficiency cannot be presented. The small number of subjects might have reduced the statistical power of the study and resulted in potential bias. Apart from those limitations above, to the best our knowledge, this was the first study evaluating the association between Vitamin D levels and VDR Fokl polymorphism among diabetic foot patient in Indonesia.

\section{Conclusion}

Most individuals with diabetic foot tended to have mutant VDR Fokl gene polymorphism and have low Vitamin D levels (Vitamin D insufficiency). These findings may highlight the potential role of Vitamin $D$ in diabetic foot complications, even in the sunlight-rich areas of the tropical region like Indonesia. It would have been valuable if we had more information on Vitamin $D$ status of our patients, and this should be considered in future studies.

\section{References}

1. World Health Organization. Global Report on Diabetes. Geneva: World Health Organization; 2016. Available from: http://www.who. int/diabetes/global-report/en. [Last accessed on 2016 Apr 12].

2. Netten JJ, Hinchliffe RJ, Forsythe RO, Vas P, MonteiroSoares M, Schaper NC, et al. Definitions and criteria for diabetic foot disease. Diabetes Metab Res Rev. 2020;36(1):e3268. https://doi.org/10.1002/dmrr.3268

PMid:31943705

3. Marchio P, Guerra-Ojeda S, Vila JM, Aldasoro M, Victor M, Mauricio MD. Targeting early atherosclerosis: A focus on oxidative stress and inflammation. Oxid Med Cell Longev 2019;8:1-32. https://doi.org/10.1155/2019/8563845

4. Zhang $\mathrm{H}$, Park $\mathrm{Y}, \mathrm{Wu} \mathrm{J}$, Chen XP, Lee $\mathrm{S}$, Yang J, et al. Role of TNF-alpha in vascular dysfunction. Clin Sci (Lond). 2009;116(3):219-30. https://doi.org/10.1042/cs20080196 PMid:19118493

5. Hinchliffe HJ, Forsythe RO, Apelqvist J, Boyko EJ, Fitridge R, Hong JP, et al. Guidelines on diagnosis, prognosis, and management of peripheral artery disease in patients with foot ulcers and diabetes (IWGDF 2019 update). Diabetes Metab Res Rev. 2020;36(1):e3276. https://doi.org/10.1002/dmrr.3276 PMid:31958217

6. Al-Daghri N, Mohammed AK, Al-Attas OS, Ansari MG, Wani K, Hussain SD, et al. Vitamin $\mathrm{D}$ receptor gene polymorphisms modify cardiometabolic response to Vitamin D supplementation in T2DM patients. Sci Rep. 2017;7:8280. https://doi.org/10.1038/ s41598-017-08621-7

7. Hiemstra TF, Lim K, Thadhani R, Manson JE. Vitamin D and atherosclerotic cardiovascular disease. J Clin Endocrinol Metab. 2019;104(9):4033-50. https://doi.org/10.1210/jc.2019-00194 PMid:30946457

8. Zostautiene I, Jorde R, Schirmer H, Mathiesen EB, Njølstad I, Løchen ML, et al. Genetic variations in the Vitamin D receptor predict Type 2 diabetes and myocardial infarction in a community-based population: The troms $\varnothing$ study. PLoS One. 2015;10(12):e0145359. https://doi.org/10.1371/journal. pone. 0145359

PMid:26699871

9. Sattar NA, Hussain F, Gillespie K, Sajid SU, Shaheen S, Shafiq $N$, et al. Role of Vitamin D receptor (VDR) genetic polymorphism in onset of Type 2 diabetes mellitus: A review. $\mathrm{J}$ Biosci Biotech Discov. 2019;4(1):1-9. https://doi.org/10.31248/ jbbd2018.077

10. Yu F, Cui L, Li X, Wang C, Ba Y, Wang L, et al. The genetic polymorphisms in Vitamin $D$ receptor and the risk of Type 2 diabetes mellitus: An updated meta-analysis. Asia Pac J Clin Nutr. 2016;25(3):614-24

PMid:27440697

11. Arai $\mathrm{H}$, Miyamoto $\mathrm{KI}$, Taketani $\mathrm{Y}$, Yamamoto $\mathrm{H}$, lemori $\mathrm{Y}$, Morita $\mathrm{K}$, et al. A Vitamin D receptor gene polymorphism in the translation initiation codon: Effect on protein activity and relation 
to bone mineral density in Japanese women. J Bone Miner Res. 1997;12(6):915-21. https://doi.org/10.1359/jbmr.1997.12.6.915 PMid:9169350

12. Chiu KC, Chuang LM, Yoon C. The Vitamin D receptor polymorphism in the translation initiation codon is a risk factor for insulin resistance in glucose tolerant Caucasians. BMC Med Genet. 2001;2:2. https://doi.org/10.1186/1471-2350-2-2 PMid:11231880

13. Li L, Wu B, Liu J, Yang L. Vitamin D receptor gene polymorphisms and Type 2 Diabetes: A meta-analysis. Arch Med Res. 2013;44(3):235-41. https://doi.org/10.1016/j arcmed.2013.02.002 PMid:23506721

14. Uitterlinden $A G$, Fang $Y$, van Meurs JB, Pols $H A$, van Leeuwen JP. Genetics and biology of Vitamin D receptor polymorphisms. Gene. 2004;338(2):143-56. https://doi. org/10.1016/j.gene.2004.05.014

PMid:15315818

15. Reis A, Hauache $O$, Velho $G$. Vitamin $D$ endocrine system and the genetic susceptibility to diabetes, obesity and vascular disease. A review of evidence. Diabetes Metab. 2005;31(4):318 25. https://doi.org/10.1016/s1262-3636(07)70200-8 PMid:16369193

16. Wang Q, Xi B, Reilly KH, Liu M, Fu M. Quantitative assessmen of the associations between four polymorphisms (Fokl, Apal, Bsml, Taql) of Vitamin D receptor gene and risk of diabetes mellitus. Mol Biol Rep. 2012;39(10):9405-14. https://doi. org/10.1007/s11033-012-1805-7

PMid:22814767

17. Pittas AG, Lau J, Hu FB, Dawson-Hughes B. The role of Vitamin $D$ and calcium in Type 2 diabetes. A systematic review and meta-analysis. J Clin Endocrinol Metab. 2007;92(6):201729. https://doi.org/10.1210/jc.2007-0298 PMid:17389701

18. Holick MF, Chen TC. Vitamin D deficiency: A worldwide problem with health consequences. Am J Clin Nutr. 2008;87(4):1080s-6. https://doi.org/10.1093/ajcn/87.4.1080s PMid:18400738

19. Kristiani AL, Sumangkut RM, Limpeleh HP. Hubungan ankle brachial index dengan keparahan ulkus pada penderita kaki diabetik. J Biomed. 2015;7(3):171-7. https://doi.org/10.35790/ jbm.7.3.2015.9488

20. Dwikayana IM, Subawa AA, Yasa IW. Gambaran HbA1c pasien diabetes melitus Tipe 2 dengan komplikasi ulkus kaki diabetik di poliklinik penyakit dalam RSUP Sanglah Denpasar periode April-September 2014. E J Med Udayana. 2016;5:7.

21. Saseedharan S, Sahu M, Chaddha R, Pathrose E, Bal A, Bhalekar $\mathrm{P}$, et al. Epidemiology of diabetic foot infections in a reference tertiary hospital in India. Braz J Microbiol. 2018;49(2):401-6. https://doi.org/10.1016/j.bjm.2017.09.003 PMid:29157899

22. Jyothylekshmy V, Menon A, Abraham S. Epidemiology of diabetic foot complications in a podiatry clinic of a tertiary hospital in South India. Indian J Health Sci Biomed Res. 2015;8(1):48-51. https://doi.org/10.4103/2349-5006.158231

23. Chandrashekar S, Muralidhar S. A study on the prevalence of risk factors and presence of diabetic foot ulcers in T2DM patients in K. R. Hospital, Mysuru. Int Surg J. 2017;4(9):2983-6. https://doi.org/10.18203/2349-2902.isj20173611

24. Zhang P, Lu J, Jing Y, Tang S, Zhu D, Bi Y. Global epidemiology of diabetic foot ulceration: A systematic review and metaanalysis. Ann Med. 2017;49(2):106-16. https://doi.org/10.1080 /07853890.2016.1231932

PMid:27585063

25. Younis BB, Shahid A, Arshad R, Khurshid S, Ahmad M, Yousaf H.
Frequency of foot ulcers in people with Type 2 diabetes, presenting to specialist diabetes clinic at a tertiary care hospital, Lahore, Pakistan. BMC Endocr Disord. 2018;18(1):53. https:// doi.org/10.1186/s12902-018-0282-y PMid:30081878

26. Apelqvist J, Agardh CD. The association between clinical risk factors and outcome of diabetic foot ulcers. Diabetes Res Clin Pract. 1992;18(1):43-53. https://doi. org/10.1016/0168-8227(92)90054-u

PMid:1446576

27. Kahuripan A, Andrajati R, Syafridani T. Analisis pemberian antibiotik berdasarkan hasil uji sensitivitas terhadap pencapaian clinical outcome pasien infeksi ulkus diabetik di RSUD Dr. H. Abdul Moeloek Lampung. Pharm Sci Res. 2012;6(2):75-87.

28. Malik R, Farooq R, Mehta P, Ishaq S, Din I, Shah P, et al. Association of Vitamin $D$ receptor gene polymorphism in patients with Type 2 diabetes in the Kashmir Valley. Can J Diabetes. 2018;42(3):251-6. https://doi.org/10.1016/j.jcjd.2017.06.003 PMid:28739347

29. Meo S, Zia I, Bukhari I, Arain S. Type 2 diabetes mellitus in Pakistan: Current prevalence and future forecast. J Pak Med Assoc. 2016;66(12):1637-42.

PMid:27924966

30. Neto A, Zantut-Wittmann D, Fernandes T, Nery M, Parisi M. Risk factors for ulceration and amputation in diabetic foot: Study in a cohort of 496 patients. Endocrine. 2012;44(1):119-24. https://doi.org/10.1007/s12020-012-9829-2

PMid:23124278

31. Soroush N, Radfar M, Hamidi AK, Abdollahi M, Qorbani M, Razi F, et al. Vitamin D receptor gene Fokl variant in diabetic foot ulcer and its relation with oxidative stress. Gene. 2017;599:8791. https://doi.org/10.1016/j.gene.2016.11.012 PMid:27836663

32. Didriksen A, Grimnes G, Hutchinson MS, Kjærgaard M, Svartberg J, Joakimsen RM. The serum 25-hydroxyvitamin D response to Vitamin D supplementation is related to genetic factors, BMI, and baseline levels. Eur J Endocrinol. 2013;169(5):559-67. https://doi.org/10.1530/eje-13-0233 PMid:23935129

33. Pourshahidi LK. Vitamin D and obesity: Current perspectives and future directions. Proc Nutr Soc. 2015;74:115-24. https:// doi.org/10.1017/s0029665114001578

PMid:25359323

34. Caron-Jobin M, Morisset AS, Tremblay A, Huot C, Légaré D, Tchernof A. Elevated serum 25(OH) D concentrations, Vitamin D, and calcium intakes are associated with reduced adipocyte size in women. Obesity (Silver Spring). 2011;19(7):1335-41. https:// doi.org/10.1038/oby.2011.90 PMid:21527900

35. Zhao $Y$, Liao $\mathrm{S}, \mathrm{He} J$, Jin $\mathrm{Y}, \mathrm{Fu} H$, Chen $X X$, et al. Association of Vitamin $D$ receptor gene polymorphisms with metabolic syndrome: A case-control design of population-based crosssectional study in North China. Lipids Health Dis. 2014;13:129. https://doi.org/10.1186/1476-511x-13-129

PMid:25106919

36. Tiwari S, Pratyush DD, Gupta SK, Singh SK. Vitamin D deficiency is associated with inflammatory cytokine concentrations in patients with diabetic foot infection. Br J Nutr. 2014;112(12):193843. https://doi.org/10.1017/s0007114514003018 PMid:25331710

37. Kayaniyil S, Vieth R, Retnakaran R, Knight JA, Qi Y, Gerstein HC, et al. Association of Vitamin D with insulin resistance and $\beta$-cell dysfunction in subjects at risk for Type 2 diabetes. Diabetes Care. 2010;33(6):1379-81. https://doi.org/10.2337/dc09-2321 PMid:20215450 
38. Zubair M, Malik A, Meerza D, Ahmad J. 25-Hydroxyvitamin D [25(OH)D] levels and diabetic foot ulcer: Is there any relationship? Diabetes Metab Syndr. 2013;7(3):148-53. https:// doi.org/10.1016/j.dsx.2013.06.008

PMid:23953180

39. Palomer X, González-Clemente JM, Blanco-Vaca F, Mauricio D. Role of Vitamin $D$ in the pathogenesis of Type 2 diabetes mellitus. Diabetes Obes Metab. 2008;10(3):185-97. https://doi. org/10.1111/j.1463-1326.2007.00710.

PMid:18269634

40. Angel $B$, Lera $L$, Márquez $C$, Albala $C$. The association of VDR polymorphisms and Type 2 diabetes in older people living in community in Santiago de Chile. Nutr Diabetes. 2018;8(1):31. https://doi.org/10.1038/s41387-018-0038-9

PMid:29795525 